\title{
ANALISIS FATWA MAJELIS ULAMA INDONESIA NOMOR 56 TAHUN 2016 TENTANG HUKUM MENGGUNAKAN ATRIBUT KEAGAMAAN NON-MUSLIM
}

\author{
Yus Afrida \\ Pascasarjana Universitas Islam Negeri Sunan Kalijaga Yogyakarta \\ Email: yusafrida20@gmail.com
}

\begin{abstract}
The Indonesian Ulema Council on 14 Rabiul Awal 1438 H coincided on December 14, 2016 issued a fatwa regarding the prohibition of using non-Muslim religious attributes. This study aims to determine the legal basis and analysis of the arguments and methods used by the Indonesian Ulema Council in deciding the fatwa regarding the prohibition of using non-Muslim religious attributes. This research method uses a normative juridical approach with the types of data in the form of secondary legal materials and primary legal materials. The findings in this study indicate that the Indonesian Ulema Council uses the holy verses of the Qur'an and hadith that talk about the prohibition of tasyabbuh (resembling non-Muslims) as the legal basis for its determination and an analysis of the arguments and methods used by the Indonesian Ulema Council only support the prohibition of tasyabbuh (similar to non-Muslims). In addition, the Indonesian Ulema Council in carrying out ijithad or legal findings always adapts to developments and changes in the social dynamics of society. This is done to obtain or find a law that is in accordance with the needs and what is happening in a society that tends to be plural.
\end{abstract}

Keyword: Keywords: Majelis Ulama Indonesia, Attributes, Religion

\begin{abstract}
Abstrak
Majelis Ulama Indonesia tanggal 14 Rabiul Awal $1438 \mathrm{H}$ bertepatan pada tanggal 14 Desember 2016 mengeluarkan sebuah fatwa tentang keharaman menggunakan atribut keagamaan non-muslim. Kajian ini bertujuan untuk mengetahui dasar hukum dan analisis terhadap dalil dan metode yang digunakan Majelis Ulama Indonesia dalam memutus fatwa tentang keharaman menggunakan atribut keagamaan non-muslim. Metode peneilitian ini menggunakan pendekatan yuridis normatif dengan jenis data berupa bahan hukum sekunder dan bahan hukum primer. Hasil penelitian menunjukkan bahwa Majelis Ulama Indonesia menggunakan ayat-ayat suci Al-Qur'an dan Hadis yang membicarakan tentang larangan tasyabbuh (menyerupai non-muslim) sebagai dasar hukum penetapannya dan analisis terhadap dalil dan metode yang digunakan Majelis Ulama Indonesia hanya mendukung pengharaman tasyabbuh (menyerupai non-muslim). Selain itu, Majelis Ulama Indonesia dalam melakukan ijtihad atau penemuan hukum selalui menyesuaikan dengan perkembangan dan perubahan dinamika sosial masyarakat. Hal tersebut dilakukan untuk mendapatkan atau menemukan hukum yang sesuai dengan kebutuhan dan yang terjadi di masyakat yang cenderung plural.
\end{abstract}

Kata Kunci: Majelis Ulama Indonesia, Atribut, Keagamaan 


\section{PENDAHULUAN}

Majelis Ulama Indonesia adalah lembaga yang menerbitkan sebuah fatwa yang dilibatkan oleh pemerintah dalam proses penerbitan suatu peraturan yang berhubungan dengan hukum Islam. Fatwa sendiri merupakan salah satu bentuk hukum yang dapat memenuhi kekosongan hukum untuk memecahkan permasalahan dalam bidang hukum Islam. Keberadaan fatwa sering terjadi setelah ada pertanyaan-pertanyaan individu maupun lembaga yang diajukanmasyarakat.Fatwa mempunyai peran penting dalam menciptakan stabilitas sosial. Perubahan sosial sebagi hasil dinamika budaya sering menimbulkan gesekan di masyarakat, Islam sebagai agama universal dengan panduan spesifik berdasarkan Al-Qur'an dan Hadis memerlukan peran ulama untuk menerjemahkan transformasi sosio-kultur dalam bentuk fatwa. Namun tidak sedikit fatwa yang kontroversi dan menimbulkan kegaduhan di masyarakat (Hamzah, 2017: 28).

Majelis Ulama Indonesia sebagai otoritas pembuat fatwa utama seharusnya dapat menjadi pihak yang inklusif dan menaungi semua kepentingan, tidak cenderung eksklusif pada satu golongan saja(Iswahyudi, 2016: 86). Fatwa yang cenderung eksklusif akan mendapat reaksi yang beragam dari masyarakat terutama bagi mereka yang merasa dirugikan dengan adanya fatwa tersebut. Fatwa merupakan produk yang diharapkan dapat meningkat mashlahah masyarakat, melindungi dan menghindarkan masyarakat dari kekeliruan memahami dan menjalankan ajaran agama (Fathoni, 2015: 78).

Setiap bentuk redaksi fatwa berdampak terhadap pemahaman masyarakat terhadap fatwa tersebut. Dalam beberapa kasus, fatwa yangdikeluarkan oleh Majelis Ulama Indonesia dianggap menghalangi kebebasan beragama bahkan berdampak pada munculnya reaksi negatif satu kelompok masyarakat terhadap kelompok yang lain. Hal ini telah terjadi dalam rentang waktu yang cukup lama, bahkan beberapa waktu setelah berdirinya Majelis Ulama Indonesia sebagai lembaga fatwa(Sajari, 2015). Demikian dengan konteks penggunaan atribut keagamaan nonmuslim bagi umat Islam menarik untuk dianalisa fatwa tentang hukum menggunakan atribut keagamaan non-muslim tersebut.

\section{METODE PENELITIAN}

Pendekatan yang digunakan dalam penelitian ini yaitu pendekatan Studi Kepustakaan, yaitu suatu penelitian yang mempergunakan bahanbahan kepustakaan sebagai sumber data bagi penelitiannya (Afiyanti et al., 2021: 35). Adapun jenis penelitian ini termasuk ke dalam penelitian pustaka yang menggunakan sumber data seperti bahan hukum primer seperti salinan Fatwa Majelis Ulama Indonesia Nomor 56 Tahun 2016 
tentang Hukum Meggunakan Atribut Keagamaan Non-Muslim. Sedangkan bahan hukum sekunder seperti buku-buku hukum termasuk skripsi, tesis, disertasi, jurnal, berita serta artikel online yang mengikat khususnya dalam bidang yang sedang diteliti.

Teknik pengumpulan data yang digunakan dalam penelitian ini yaitu dengan melakukan penentuan bahan hukum, inventarisasi (dokumen) bahan hukum yang relevan dan sesuai dengan isu hukum dan pengkajian dari berbagai bahan hukum. Kemudian penulis melakukan penelitian pustaka ini dengan cara membaca terlebih dahulu buku-buku terkait penelitian. Setelah dibaca, penulis melakukan telaah terhadap bacaan yang telah dibaca dan selanjutnya penulis melakukan analisis serta langsung mengutip beberapa kalimat yang sesuai dengan penelitian yang penulis lakukan untuk dimasukkan ke dalam bagian penelitian ini.

\section{PEMBAHASAN}

\section{Dasar Hukum yang Digunakan Majelis Ulama Indonesia dalam Fatwa tentang Hukum Menggunakan Atribut Keagamaan Non-Muslim}

Pengeluaran fatwa Majelis Ulama Indonesia tentang Hukum menggunakan Atribut Keagamaan Non-Muslim pada tanggal 14 Desember 2016 merupakan jawaban atas pertanyaan yang diajukan oleh masyarakat terhadap Majelis Ulama Indonesia mengenai pakaian keagamaan non-muslim. dalam menimbang fatwa ini menjelaskan bahwa adanya sebagian pemilik usaha seperti hotel, supermarket, departemen store, restoran dan lain sebagaina mengharuskan karyawannya termasuk yang muslim untuk menggunakan atribut keagamaan dari non-muslim. fatwa ini juga menjelaskan bahwa yang dimaksud dengan menggunakan atribut dan/atau simbol keagamaan non-muslim yaitu atribut keagamaan yang berdampak pada syiar keagamaan non-muslim.

Majelis Ulama Indonesia dalam menetapkan hukum menggunakan atribut keagamaan non-muslim menggunakan beberapa dalil yang dijadikan dasar hukum. dalil-dalil yang digunakan oleh Majelis Ulama Indonesia antara lain surat AL-Baqarah ayat 104 berbunyi :

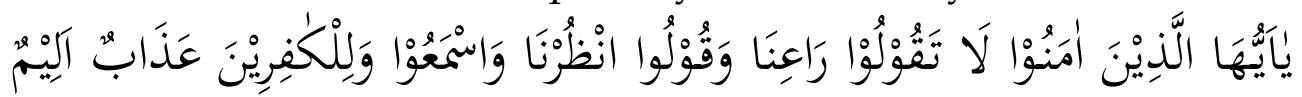

Artinya: "Hai orang-orang yang beriman, janganlah kamu katakan (kepada Muhammad): 'Rââ'inâ' tetapi katakanlah: 'Unzhurnâ', dan 'dengarlah'. Danbagi orang-orang yang kafir siksaan yang pedih." (QS. Al-Baqarah: 104).

Ayat ini yang dijadikan oleh Majelis Ulama Indonesia sebagai dasar pengharaman menggunakan atribut keagamaan non-muslim. Tujuan dari ayat ini ialah melarang kaum mukmin menyerupai orang-orang kafir dalam ucapan dan perbuatannya. Fatwa Majelis Ulama Indonesia ini juga 
merekomendasikan agar umat Islam tetap menjaga kerukunan umat beragama, saling menghormati keyakinan dan kepercayaan setiap agama, namun bukan dengan saling mengakui kebenaran teologis.

Dalam rekomendasi Nomor 3 disebutkan pula agar umat Islam tidak memproduksi, memberi dan meperjualbelikan atribut keagamaan nonmuslim. selain itu, Majelis Ulama Indonesia pun menyebutkan agar pimpinan perusahaan menjamin hak umat Islam dengan tidak memaksakan kehendak karyawannya untuk menggunakan atribut kegamaan non-muslim. Majelis Ulama Indonesia merekomendasikan pula agar pemerintah wajib mencegah dan mengawasi pihak-pihak yang membuat aturan atau melakukan ajakan kepada karyawan muslim untuk menggunakan atribut keagamaan non muslim. Dalam fatwanya Majelis Ulama Indonesia juga mencantumkan Surah al-Mujadalah Ayat 22 yang berbunyi:

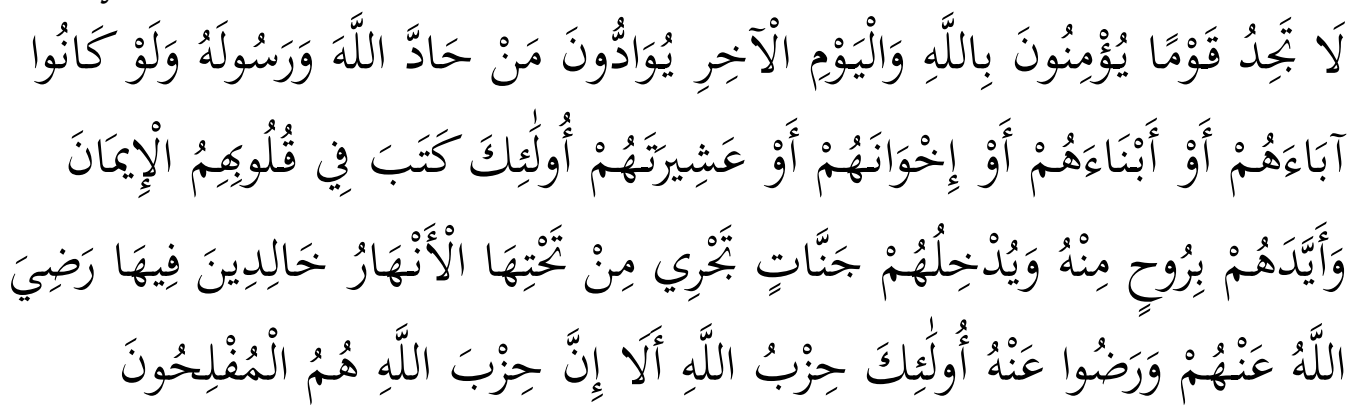

Artinya: "Kamu tak akan mendapati kaum yang beriman pada Allah dan hari akhirat, saling berkasih-sayang dengan orang-orang yang menentang Allah dan Rasul-Nya, sekalipun orang-orang itu bapak-bapak, atau anak-anak atau saudara-saudara ataupun keluarga mereka. Mereka itulah orang-orang yang telah menanamkan keimanan dalam hati mereka dan menguatkan mereka dengan pertolongan yang datang daripada-Nya. Dan dimasukan-Nya mereka ke dalam surga yang mengalir di bawahnya sungai-sungai, mereka kekal di dalamnya. Allah ridha terhadap mereka, dan merekapun merasa puas terhadap (limpahan rahmat)-Nya. Mereka itulah golongan Allah. Ketahuilah, bahwa sesungguhnya hizbullah itu adalah golongan yang beruntung (QS. Al-Mujâdilah : 22).

Selain ayat Al-Qur'an di atas yang dijadikan dasar oleh Majelis Ulama Indonesia dalam penetapan fatwa ini, Majelis Ulama Indonesia juga menjadikan hadist sebagai dasar penetapan fatwanya, terdapat lima hadist yang dijadikan pertimbangan tentang hukum menggunakan atribut keagamaan non-muslim. Kelima Hadis itu di antaranya sebagai berikut:

a. "Dari Ibnu Umar ra, dari Rasulullah SAW beliau bersabda: Selisihilah kaum musyrikin, biarkanlah jengot panjang dan pendekkanlah 
kumis." (HR. al- Bukhari dan Muslim).

b. Dari Abi Sa'id al-Khudri ra dari Nabi SAW: Sesungguhnya kalianbenar-benar akan mengikuti tuntutan orang-orang sebelum kalian, sejengkal demi sejengkal dan sehasta demi sehasta, sampai seandainya mereka memasuki lubang biawak pun tentu kalian mengikuti mereka juga. Kami berkata: Wahai Rasulullah, Yahudi dan Nashara? Maka beliau berkata: Maka siapa lagi?." (HR. al-Bukhari dan Muslim)

c. Dari Ibnu Umar ra, Rasulullah SAW bersabda: Aku diutus dengan pedang menjelang hari kiamat hingga mereka menyembah Allah Ta'ala semata dan tidak mempersekutukan-Nya dengan sesutaupun, dan telah dijadikan rizkiku di bawah bayangan tombakku, dijadikan kehinaan dan kerendahan bagi siapa yang menyelisihi perkaraku. Dan barang siapa menyerupai suatu kaum maka ia termasuk bagian dari mereka." (HR.Ahmad).

d. Dari Ibnu Umar ra, Rasulullah SAW bersabda: Barang siapa yangmenyerupai suatu kaum maka dia termasuk dalam golongan mereka." (HR. Abu Dawud).

e. Dari Amru bin Syu'aib dari ayahnya dari kakeknya sesungguhnya Rasulullah SAW bersabda: Bukan dari golongan kami orang yang menyerupai selain kami, maka janganlah kalian menyerupai Yahudi dan Nasrani, karena sungguh mereka kaum Yahudi memberi salam dengan isyarat jari jemari dan kaum Nasrani memberi salam dengan isyarat telapak tangannya." (HR. al- Tirmidzi).

Selanjutnya Majelis Ulama Indonesia dalam fatwa tentang hukum menggunakan atribut keagamaan non-muslim juga menggunakan metode ushul figh dan kaidah fidhiyyah. Untuk metode ushul figh yang digunakan oleh Majelis Ulama Indonesia yaitu metode sadd al-dzari'ah yang terdapat dalam fatwa berupa:

"Dengan mencegah sesuatu perbuatan yang lahiriyahnya boleh akan tetapi dilarang karena dikhawatirkan akan mengakibatkan pebuatan yang haram, yaitu pencampuradukkan antara yang haq dan yang bathil."

Untuk kaidah fidhiyyah yang digunakan oleh Majelis Ulama Indonesia yaitu "Mencegah kemafsadatan lebih didahulukan (diutamakan) daripadamenarik kemashlahatan". Ulama Indonesia dalam menentukan hukum juga memperhatikan pendapat Imam Madzhab yang mendukung pengharaman fatwa tentang hukum menggunakan atribut keagamaan non-muslim. pendapat Imam yang pertama ialah Imam Khatib AlSyarbini dalam Kitab "Mughni al-Muhtaj ila Ma'rifati alfazh al-Minhaj", Jilid 5 Halaman ke 562 yang berbunyi:

"Dihukum ta'zir terhadap orang-orang yang menyamai dengan kaum kafir dalam hari-hari raya mereka, orang-orang yang 
mengurung ular dan masuk ke dalam api, dan orang yangberkatakepada seorang kafir dzimmi'Ya Hajj', dan orang yang mengucapkan selamat kepadanya (kafir dzimmi) di hari raya (orang kafir)".

Kitab ini menjelaskan tentang hukuman ta'zir bagi orang yang menyamai orang kafir dan orang yang mengucakan selamat kepada kepada orang kafir.Pendapat yang kedua yaitu pendapat dari Imam Jalaluddin As- Suyuthi dalam Kitab "Haqiqat as-Sunnah wa al-Bid'ah: alAmru bi al-Intiba wa al-Nahyu al-Ibtida'", Halaman 4 yang berbunyi:

“Termasuk bid'ah dan kemungkaran adalah sikap menyerupai (tasyabbuh) dengan orang-orang kafir dan menyamai mereka dalam hari-hari raya dan perayaan-perayaan mereka yang dilaknat (oleh Allah). Sebagaimana dilakukan banyak kaum muslimin yang tidak berilmu yang ikut-ikutan orang-orang Nasrani dan menyamai mereka dalam perkara yang mereka lakukan... adapun menyerupai orang kafir hukumnya haram sekalipun tidak bermaksud menyerupai".

Kitab ini menjelaskan bahwa tasyabbuh (menyerupai orang kafir) termasuk bid'ah dan kemungkaran. Adapun menyerupai orang kafir hukumnya adalah haram walaupun tidak bermaksud menyerupai.Atribut keagamaan non-muslim yang dimaksud dengan Majelis Ulama Indonesia ialah yang terdapat pada bagian ketentuan umum yang bebrunyi bahwa atribut keagamaan non-muslim adalah sesuatu yang dipakai dan digunakan sebagai identitas, ciri khas atau tanda tertentu dari suatu agama dan/atau umat beragama tertentu, baik terkait dengan keyakinan, ritual ibadah maupun tradisi dari agama tertentu. Untuk ketentuan hukumnya ada dua ketentuan hukum yaitu pertama, Menggunakan atribut keagamaan non-muslim adalah haram; kedua, Mengajak dan/atau memerintahkan penggunaan atribut keagamaan non-muslim adalah haram.

\section{Analisis Terhadap Dasar Hukum yang Digunakan dalam Fatwa Tentang Hukum Menggunakan Atribut Keagamaan Non-Muslim}

Indonesia merupakan negara yang majemuk. Indonesia terdiri dariberbagai suku, bahasa, adat istiadat dan agama. Bangsa Indonesia hidup tersebar dalam ribuan dalam pulau, persebaran penduduk di pulau-pulau tersebut tidak merata, ada pulau yang relatif kecil dengan penduduk yang sangat padat dan ada yang luas tetapi dihuni oleh penduduk yang sangat minim. Bangsa Indonesia juga menganut berbagai macam agama dan Islam merupakan agama yang mayoritas.

Keragaman dalam segala segi kehidupan merupakan realitas yang tidak mungkin untuk dihindari. Ada masa ketika keragaman menjadi kebanggaan bersama, dan ada pula masa ketika keragaman menjadi 
sebuah petaka. Segenap pengalaman ini seyogyanya menjadi bahan pemikiran bersama untuk mengembangkan model-model penyelesaian yang tepat terhadap setiap konflik dan memikirkan langkah-langkah yang strategis dan sistematis untuk membangun kesadaran, pemahaman dan sikap positif terhadap realitas keragaman (Naim, 2011: 25). UndangUndang Dasar Negara Republik Indonesia Tahun 1945 Pasal 29 tentang agama disebutkan bahwa negara berdasarkan atas Ketuhanan Yang Maha Esa dan negara menjamin kemerdekaan tiap-tiap penduduk untuk memeluk agamanya masing-masing dan untuk beribadat menurut agamanya dan kepercayaannya itu.

Majelis Ulama Indonesia dalam pertimbangannya untuk menentukan fatwa ini dikarenakan telah terjai dalam masyarakat luas di mana saat peringatan hari besar agama non-Islam, sebagian umat Islam atas dasar toleransi dan persahabatan, justru mereka menggunakan atribut dan/atau simbol keagamaan non-muslim untuk memeriahkan kegiatan keagamaan non-Islam tersebut. Ada sebagian pemilik usaha seperti hotel, supermarket, departemen store, restaurant dan lain sebagainya, bahkan kantor pemerintahan pun mengharuskan karyawannya termasuk yang muslim untuk menggunakan atribut keagamaan non-muslim.

Fenomena ini menimbulkan pertanyaan mengenai apa hukum menggunakan atribut keagamaan non-muslim. Oleh sebab itu, Majelis Ulama Indonesia memandang perlu menetapkan sebuah fatwa tentang hukum menggunakan atribut keagamaan non-muslim. Adapun hukum yang ditetapkan Majelis Ulama Indonesia dalam fatwa tersebut ialah haram. Ketetapan ini banyak menuai pro dan kontra. Sebagian beranggapan bahwa penggunaan atribut keagamaan non-muslim tersebut sebagai bentuk toleransi antar umat beragama. Dan sebagian pula ada yang beranggapan bahwa penggunaan atribut keagamaan tersebut dapat berdampak pada syiar keagamaan Islam.

Toleransi dalam pergaulan antar umat beragama bermula dari penghayatan ajaran agama masing-masing. Demi memelihara kerukunan beragama, sikap toleransi harus dikembangkan untuk menghindari konflik. Dan terkait ketakutan yang akan menimbulkan dampak pada syiar keagamaan Islam, itu semua bergantung pada niatan penggunaan atribut keagamaan non-muslimtersebut. Dalil yang digunakan Majelis Ulama Indonesia dalam penetapan fatwa berdasarkan Al-Qur'an (AlBaqarah: 104 menjelaskan tentang larangan meniru perkataan orangorang kafir, al-Baqarah: 42 menjelaskan tentang larangan mencampuradukkan yang haq dan yang bathil, al- Kâfirûn: 1-6 menjelaskan tentang toleransi dan hubungan antar agama, khususnya terkait ibadah, al-An'âm: 153 menjelaskan larangan mengikuti jalan, petunjuk dan syiar selain Islam, al-Mumtahanah: 8 menjelaskan tidak 
melarang orang Islam bergaul dan berbuat baik dengan orang kafir yang tidak memusuhi Islam dan al-Mujâdilah: 22 yang mengkabarkan bahwa orang mukmin tidak bisa saling berkasih sayang dengan orang yang menentang Allah SWT dan Rasul-Nya.) dan Hadist Rasulullah SAW yang melarang muslim menyerupai non-muslim. Sedangkan untuk qiyas fatwa Majelis Ulama Indonesia menjadikan larangan tasyabbuh dalam dasar hukumnya.

\section{Analisis Terhadap Metode yang Digunakan dalam Fatwa Tentang Hukum Menggunakan Atribut Keagamaan Non-Muslim}

Majelis Ulama Indonesia dalam menetapkan fatwa tentang hukum menggunakan atribut keagamaan non-muslim ini men-qiyas-kannya dengan tasyabbuh. Tasyabbuh berasal dari kata al-musyabahah yang berarti meniru atau mencontoh, menjalin atau mengaitkan dan mengikuti.Attasybih berarti peniruan, dan mutasyabihah berarti mutamatsilat (serupa). Dapat dikatakan serupa dengannya, meniru dan mengikutinya.

Menurut al-Munawi, tasyabbuh bermaksud berhias seperti mana mereka berhias, berusaha mengenali sesuai dengan perbuatan mereka, berakhlak dengan akhlak mereka, berjalan seperti mereka berjalan, menyerupai mereka dalam berpakaian dan sebahagian perbuatan mereka. Adapun tasyabbuh yang sebenarnya ialah bertepatan dari segi aspek zahir dan batin (Frinaldi \& Embi, 2011: 34). Berkaitan dengan larangan tasyabbuh di atas, Allah SWT berfirman Al-Baqarah: 120 yang artinya "Orang-orang Yahudi dan Nasrani tidak akan senang kepada kamu hingga kamu mengikuti agama mereka. Katakanlah: Sesungguhnya petunjuk Allah itulah petunjuk (yang benar). Dan sesungguhnya jika kamu mengikuti kemauan mereka setelah pengetahuan datang kepadamu, maka Allah tidak lagi menjadi pelindung dan penolong bagimu".

Allah SWT dalam ayat ini memberi kabar pada kata "millatahum" yang artinya agama mereka (Hamzah, 2017: 64). Akan tetapi ketika melarang, Allah SWT mengungkapkannya dengan kata "ahwa'ahum" karena kaum Nasrani dan Yahudi tidak akan senang kepada kamu kecuali mengikuti agama mereka secara mutlak. Termasuk dalam mengikuti dengan menyerupai mereka, karena menyerupai mereka berarti mengikuti keinginan mereka. Maka orang-orang kafir sennag jika orangorang Islam menyerupai sebahagian dari pada urusan mereka. Ini disebebkan dengan menyerupai satu urusan, bisa menjadi pendorong untuk menyerupai dalam hal-hal yanglainnya(Ansori, 2018: 14).

Dasar-dasar hukum yang digunakan oleh Majelis Ulama Indonesia dalam menetapkan fatwa tentang hukum menggunakan atribut keagamaan non-muslim hampir dari semua dalil yang dicantumkandalam penetapan fatwa membahas tentang pelarangan tasyabbuh. Dalil- dalil yang menunjukkan tasyabbuh (penyerupaan dengan non-muslim) hampir 
keseluruhannya melarang. Terdapat beberapa kaidah umum yang telah digariskan oleh para ulama yang dapat menjadi kriteria utama bagi mengklasifikasikan sebuah amalan sebagai tasyabbuh dan dalam menetapkan sikap yang perlu diambil dalam berhadap dengan isu ini (tasyabbuh) (Abbas, 2004: 84). Di antaranya kriteria tersebut sebagai berikut:

a. Bukan termasuk tasyabbuh melainkan dengan niat, artinya bahwa sesuatu perbuatan tidak disebut sebagai tasyabbuh jika tidak disertai dengan niat, karena tasyabbuh terjadi apabila pelaku perbuatan tersebut bertujuan untuk bertasyabbuh;

b. Terdapat hukum keharaman dan ada pula hukum yang mubah terkait penyerupaan di hari raya orang non-muslim yang dilakukan orang Islam;

c. Segala bentuk hari raya dan hari besar secara umum berpengaruh besar pada agama dan duniaseseorang.

Menurut penulis, dari 3 (tiga) kriteria di atas, jika dikaitkan dengan pegawai yang disuruh atasannya untuk memakai atribut keagamaan nonIslam diberbagai tempat-tempat usaha seperti hotel, departemen store, restoran, dan lain sebagainya itu boleh untuk dilakukan asal dengan niat tidak untuk memeriahkan agama non-Islam, tetapi untuk menghargai kehidupan beragama dan adat istiadat. Hal ini dilakukan untuk menjaga nama baik agama Islam agar tidak dipandang sebelah mata oleh masyarakat awam karena terlalu kaku dan tidak menghargai agama lain. Dalam hal ini tidak seharusnya Majelis Ulama Indonesia terlalu kaku dalam mengeluarkan suatu hukum baru berupa pengeluaran sebuah fatwa.Hal ini pula sudah disinggung oleh Imam Muhammad Amin dari kalangan petinggi madzhab Hanafi yang juga pengarang Kitab "al-Dur alMukhtar" yang mengatakan bahwa:

"Tidak selamanya tasyabbuh (menyerupai orang non-muslim) itu negatif dan dibenci. Kecuali tasyabbuh pada keburukan dan yang memang diniatkan untuk meniru gaya mereka".

Dalam perumusan hukum membutuhkan perlengkapan teknis intelektual untuk menganalisis dalil-dalil normatif dalam Islam. Sedangkan dalam menerapkan hukum memerlukan analisis sosial, ekonomi dan politik, maka dalam sebuah fatwa diperlukan analisis apakah fatwa tersebut akan berpengaruh baik atau buruk bagi bangsa Indonesia.Sebagaimana sebagian ulama berpendapat, bahwa kata tasyabbuh bisa digunakan dalam konteks kebaikan dan dosa. Dalam kitab 'Aun a'- Ma'bud diterangkan bahwa:

"Barang siapa bertasyabbuh dengan orang-orang shalehh, maka ia akan dimuliakan sebagaimana orang-orang shaleh itu dimuliakan. Barang siapa bertasyabbuh dengan orang-orang fasik, maka ia tidak akan dimuliakan. Siapa saja yang memiliki ciri-ciri orang-orang 
mulia maka ia mulia, meskipun kemuliaan itu belum berwujud".

Selain soal pengharaman atribut keagaman non-muslim, fatwa ini turut merekomendasikan pentingnya menjaga kerukunan hidup antar umat beragama dan memelihara harmoni kehidupan bermasyarakat, berbangsa dan bernegara tanpa menodai ajaran agama, serta tidak mencampuradukkan antara akidah danibadah Islam dengan keyakinan agama lain. Fatwa tersebut juga menegaskan pentingnya umat Islam agar saling menghormati keyakinan dan kepercayaan setiap agama. Salah satunya adalah dengan menghargai kebebasan non-muslim dalam menjalankan ibadahnya, bukan saling mengakui kebenaran teologis. Pernyataanpernyataan tersebut tertuang dalam poin-poin rekomendasi fatwa yang ditandatangani oleh Prof. Dr. H. Hasanuddin AF, MA, Dr. H. M. Asrorun Ni'am Sholeh, MA selaku penanggungjawab Komisi Fatwa Majelis Ulama Indonesia (MUI) Pusat.

Fatwa ini terdiri dari empat bagian, dan masing-masing bagian memuat penjelasan-penjelasan detail terkait isu penggunaan atribut keagamaan agama lain. Bagian pertama memuat pertimbanganpertimbangan logis di balik lahirnya fatwa tersebut sementara di bagian kedua merinci berbagai dalil yang menjadi dasar dalam penetapan fatwa, baik dari Alquran, hadis maupun kaidah-kaidah fqhiyyah. Pada bagian ketiga, fatwa ini mengutip berbagai pendapat ulama terkait isu-isu yang dianggap serupa dengan isu penggunaan atribut keagamaan. Pada bagian akhir, fatwa merumuskan tiga poin utama yaitu defnisi atribut keagamaan, ketentuan hukum penggunaan atribut keagamaan nonmuslim dan 6 poin rekomendasi.

Kerukunan antar-umat beragama yang dimaksud di sini adalah perihal hidup dalam suasana yang baik dan damai, tidak bertengkar, bersatu hati, dan bersepakat antar umat beragama yang berbeda-beda agamanya atau antar umat beragama dalam satu agama. Kerukunan antar umat beragama bukan berarti melebur agama-agama yang ada menjadi satu totalitas (sinkretisme agama), melainkan sebagai cara atau sarana untuk mempertemukan, mengatur hubungan luar antara orang yang tidak seagama atau antara golongan umat beragama dalam setiap proses kehidupan sosial kemasyarakatan.Yaitu semua orang bisa "hidup bersama tanpa kecurigaan, dimana tumbuh semangat dan sikap saling menghormati dan kesediaan untuk bekerja sama demi kepentingan bersama (Daulay, 2001: 52).

Kerukunan atau hidup rukun adalah sikap yang berasal dari lubuk hati yang terdalam, terpancar dari kemauan untuk memang berinteraksi satu sama lain sebagai manusia tanpa tekanan dari pihak manapun (Taher, 2009: 27), dengan adanya yang satu mendukung keberadaan yang lain (Haq, 2002: 36). 
Hubungan antar agama di Indonesia masih dihadapkan pada berbagai persoalan, tantangan dan juga mengalami pasang surut. Ada kalanya hubungan tersebut berlangsung harmonis, tetapi tidak jarang berujung pada konfik yang menyebabkan jatuhnya korban jiwa. Rangkaian konfik dan kekerasan bernuansa agama terus terjadi di Indonesia, mulai dari kerusuhan bernuansa agama di kota-kota provinsi pada 1995-1997, kampanye anti hukum santet di Jawa dan konfik antar kelompok agama di Sulawesi Tengah dan Maluku 1998-2001, hingga mobilisasi laskar berbasis agama danpengeboman yang dilakukan kelompok teroris atas nama jihad pada 2000-2005 (Fauzi, 2009: 47).

Salah satu contohnya adalah tasbih (dalam Kristen: rosario), yang tidak murni berasal dari Islam, karena itu dianggap bid'ah oleh satu kelompok dalam Islam. Di Indonesia, ada kentongan untuk masjid yang pernah menjadi perdebatan di kalangan kiai NU generasi awal, satu menganggapnya bid'ah yang lain membolehkannya (Syafaq, 2014: 22). Selanjutnya menara yang berasal dari kata Arab manarah (tempat perapian) untuk masjid; satu pendapat menyatakan menara diadopsi dari tradisi Zoroastrian; pendapat lain menyatakan ia berasal dari gereja Kristen Suriah yang ketika berada di bawah dinasti Umawi, diubah menjadi masjid. Hal lain seperti baju koko, yang bermula dari tradisi Tionghoa (tampak dari namanya: "engkoh-engkoh" menjadi "koko"). Lebih jauh bila atribut juga mencakup simbol, bahwa lambang nasional kita, burung Garuda, yang berasal dari tradisi Hindu: Garuda adalah tunggangan (vahana) Wisnu.

Melihat sejarah tersebut maka timbul pertanyaan, atribut seperti apa yang dimaksud dalam fatwa MUI tersebut? Pertama, pada tataran judul dan butir-butir keputusan fatwa tersebut tidak secara eksplisit dinyatakan bahwa yang dimaksud dengan istilah non-muslim adalah umat atau pemeluk agama Kristen. Namun dari latar belakang dan konteks terbitnya fatwa ini dapat dipahami bahwa yang dimaksud dengan istilah itu adalah umat Kristen.

Jika kita melihat sejarah menunjukkan bahwa kepemilikan terhadap suatu atribut sesungguhnya dari mengikuti perkembangan zaman, apa yang sebelumnya menjadi tradisi agama atau budaya lain dan kemudian menjadi tradisi bersama (Fachruddin, 2016: 31). Salah satu contohnya adalah tasbih (dalam Kristen: rosario), yang tidak murni berasal dari Islam, karena itu dianggap bid'ah oleh satu kelompok dalam Islam. Di Indonesia, ada kentongan untuk masjid yang pernah menjadi perdebatan di kalangan kiai NU generasi awal, satu menganggapnya bid'ah yang lain membolehkannya (Syafaq, 2014: 12). Selanjutnya menara yang berasal dari kata Arab manarah (tempat perapian) untuk masjid; satu pendapat menyatakan menara diadopsi dari tradisi Zoroastrian; pendapat lain menyatakan ia berasal dari gereja Kristen Suriah yang ketika berada di 
bawah dinasti Umawi, diubah menjadi masjid. Hal lain seperti baju koko, yang bermula dari tradisi Tionghoa (tampak dari namanya: "engkohengkoh" menjadi "koko").

Lebih jauh bila atribut juga mencakup simbol, bahwa lambang nasional kita, burung Garuda, yang berasal dari tradisi Hindu: Garuda adalah tunggangan (vahana) Wisnu. Dengan melihat sejarah tersebut maka timbul pertanyaan, atribut seperti apa yang dimaksud dalam fatwa MUI tersebut? Pertama, pada tataran judul dan butir-butir keputusan fatwa tersebut tidak secara eksplisit dinyatakan bahwa yang dimaksud dengan istilah non-muslim adalah umat atau pemeluk agama Kristen. Namun dari latar belakang dan konteks terbitnya fatwa ini dapat dipahami bahwa yang dimaksud dengan istilah itu adalah umat Kristen.

Berdasarkan uraian di atas, dapat disimpulkan bahwa kata tasyabbuh jika dilihat dari pengertian secara bahasa (haqiqat al-lughawiyyah), maka pemaknaan kata tasyabbuh bisa digunakan dalam konteks kebaikan dan juga keburukan. Oleh karena itu perlu pemaknaan tasyabbuh secara syar'i (haqiqat al-syar'iyyah (Hamali, 2011: 74)). Tasyabbuh yang dimaknai dengan bentuk penyerupaan terhadap sesuatu, maka memiliki koneskuensi hukum bahwa ada tasyabbuh yang dibolehkan dan ada tasyabbuh yang dilarang.

Menyerupai yang diperbolehkan adalah suatu tingkah laku yang merupakan perkara dunia meskipun awalnya bukan berasal dari Islam, namun tidak menimbulkan kerusakan atau membawa mafsadat, maka dalam hal ini tidak dilarang menyerupai (Raharjo, 2009: 37). Namun akan berbeda konsekuensinya jika tasyabbuh di sini dimaknai dengan penyerupaan terhadap orang kafir (tasyabbuh bil Kuffar). Syaikh Utsaimin berkata:

“Standar Tasyabbuh adalah pelakunya melakukan sesuatu yang merupakan ciri khas yang diserupainya. Mislanya yang disebut menyerupai orang-orang kafir adalah seorang muslim melakukan sesuatu yang merupakan ciri khas mereka (orang kafir). Adapun jika hal tersebut telah berlaku umum di kalangan kaum muslimin dan hal itu tidak merupakan ciri khas dari orang-orang kafir maka yang demikian bukan tasyabbuh, sehingga hukumnya tidak haram karena penyerupaan tersebut, kecuali jika hal itu haram bila dilihat dari siis lain. Inilah yang kami maksud dengan relatifitas maksud kalimat."

Penulis buku al-Fath pada Juz 10 halaman 272 menyebutkan: sebagian salaf tidak menyukai pemakaian burnus karena merupakan aksesoris para pendeta. Imam Malik pernah ditanya mengenai hal ini,beliau mengatakan: Tidak apa-apa. Lalu dikatakan, bahwa itu pakaian orang Nasrani. Beliau menjawab, dulu itu dipakai di sini. Menurut saya: seandainya ketika Imam Malik ditanya masalah ini beliau berdalih 
dengan sabda Nabi Muhammad SAW tentang orang yang sedang ihram tidak boleh mengenakan gamis, imamah, celana dan juga burnus, tentu akan lebih baik. Dan di dalam al-Fath Juz I halaman 307 juga disebutkan, jika kita katakana itu terlarang karena menyerupai orang-orang non-arab, maka hal ini demi kemashlahatan agama, tentunya karena hal itu tidak termasuk simbol mereka dan mereka adalah orang-orang kafir (Morris, 2011: 54). Kemudian tatkala hal ini sekarang tidak lagi menjadi simbol dan ciri khas mereka, maka hilanglah makna tersebut sehingga hilang pula hokum makruhnya

Hal penting yang wajib di garis bawahi dari pernyataan beliau di atas yaitu bahwa adanya kemungkinan sesuatu yang pada awalnya memang bukan berasal dari Islam, namun kemudian hal tersebut sudah menjadi umum bahkan di kalangan umat Islam itu sendiri dan tidak lagi menjadi kekhususan bagi orang-orang kafir. Maka tasyabbuh yang seperti ini tidak lagi menjadi haram hukumnya. Contohnya, dalam pemakaian dasi dan jas. Awalnya memang bukan berasal atau dimulai dari umat Islam, namun hal ini sudah menyebar dan menjadi umum di kalangan umat Islam sehingga tidak adanya lagi lebel bahwa perkara tersebut merupakan kekhususan bagi orang-orangkafir.

Berdasarkan paparan di atas, penulis berpendapat bahwa apa yang dilakukan oleh Majelis Ulama Indonesia sebagai penjagadan pengayom umat Islam sudah tepat, yakni dengan tegas menyatakan bahwa menggunakan atribut keagamaan non-muslim ialah haram. Dan mengajak dan/atau mmerintahkan penggunaan atribut keagamaan non-muslim ialah haram. Majelis Ulama sudah menjalankan tugas utamanya dalammemelihara keyakinan dalam praktik keagamaan umat Islam. fatwa ini dibuat dalam rangka penghormatan kepada prinsip kebhinekaan dan kerukunan beragama di Indonesia. Makna dari kebhinekaan ialah kesadaran terhadap perbedaan termasuk perbedaan terhadap keyakinan agama, sehingga harus saling menghormati dan tidak memaksakan keyakinan tersebut pada orang lain. Setiap bentuk pemaksaan keyakinan kepada orang lain bertentangan dengan Hak Asasi Manusia dan Konstitusi.

\section{SIMPULAN}

Simpulan dari penelitian ini ialah dalil yang digunakan Majelis Ulama Indonesia dalam penetapan fatwa menggunakan dalil-dalil yang mendukung pengharaman tasyabbuh (menyerupai orang non-muslim). Terdapat 3 (tiga) kriteria yang jika dikaitkan dengan pegawai yang disuruh atasannya untuk memakai atribut keagamaan non-Islam diberbagai tempat-tempat usaha seperti hotel, departemen store, restoran, supermarket dan lain sebagainya itu boleh untuk dilakukan asal dengan niat tidak untuk memeriahkan agama non-Islam, tetapi untuk menghargai 
kehidupan beragama dan adat istiadat. Hal ini dilakukan untuk menjaga nama baik agama Islam agar tidak dipandang sebelah mata oleh masyarakat awam karena terlalu kaku dan tidak menghargai agama lain. Dalam hal ini tidak seharusnya Majelis Ulama Indonesia terlalu kaku dalam mengeluarkan suatu hukum baru berupa pengeluaran sebuah fatwa.

Analisis terhadap metode yang digunakan Majelis Ulama Indonesia dalam penetapan fatwa berisikan tentang tasyabbuh (menyerupai orang non- muslim). apa yang dilakukan Majelis Ulama Indonesia sebagai penjagadan pengayom umat Islam sudah tepat, yakni dengan tegas menyatakan bahwa menggunakan atribut keagamaan non-muslim ialah haram. Dan mengajak dan/atau mmerintahkan penggunaan atribut keagamaan non-muslim ialah haram. Majelis Ulama sudah menjalankan tugas utamanya dalam memelihara keyakinan dalam praktik keagamaan umat Islam. fatwa ini dibuat dalam rangka penghormatan kepada prinsip kebhinekaan dan kerukunan beragama di Indonesia. Makna dari kebhinekaan ialah kesadaran terhadap perbedaan termasuk perbedaan terhadap keyakinan agama, sehingga harus saling menghormati dan tidak memaksakan keyakinan tersebut pada orang lain. Setiap bentuk pemaksaan keyakinan kepada orang lain bertentangan dengan Hak Asasi Manusia danKonstitusi.

\section{DAFTAR PUSTAKA}

\section{Buku-buku}

Abbas, A. S. (2004). Qawa'id Fiqhiyyah dalam Perspektif Figh. Pedoman Ilmu Jaya dengan Angko Medi.

Afiyanti, V., Bilqis, I., Surabaya, U. N., Harfi, D. E., Surabaya, U. N., Prasetio, D. E., Surabaya, U. N., Firdaus, Y., \& Surabaya, U. N. (2021). Teori-Teori dalam Sosiologi Hukum. January.

Daulay, M. Z. (2001). Mereduksi Konfik Antarumat Beragama di Indonesia. Badan Litbang Agama dan Diklat Keagamaan Departemen Agama RI.

Fauzi. (2009). Pola-pola Konfik Keagamaan di Indonesia ( (The Asia F).

Haq. (2002). Jaringan Kerjasama Antarumat Beragama: Dari wacana ke aksi nyata. Titahandalusia Press.

Muhammad Syamsul Haq, Aunul Ma'bud Syarh Sunan Abi Dawud, Juz VI, (Beirut- Lebanon: Darul Kutub Ilmiyyah, 1990), h. 51. (n.d.).

Naim, N. (2011). Teologi Mencari Kerukunan. Teras.

Raharjo, S. (2009). Penegakan Hukum suatu tinjauan sosiologis. Genta Publishing. 
Taher. (2009). Merayakan Kebebasan Beragama Bunga Rampai 70 Tahun Djohan Effend. ICRP.

\section{Jurnal-jurnal}

Ansori, L. (2018). Reformasi Penegakan Hukum Perspektif Hukum Progresif. Jurnal Yuridis, 4(2), 148. https:/ / doi.org/10.35586/.v4i2.244

Fachruddin. (2016). Fatwa MUI, Atribut Natal, dan Soal Kerukunan. In My Hat's Off to the pauses that refreshes. CRCS, 12(2).

Fathoni, N. (2015). Analisis Normatif-Filosofis Fatwa Dewan Syari'ah Nasional Majelis Ulama Indonesia (DSN-MUI) Tentang Transaksi Jual Beli Pada Bank Syari'ah. Jurnal Al-Ahkam, 25(2).

Frinaldi, A., \& Embi, M. A. (2011). Pengaruh Budaya Kerja Etnik terhadap Budaya Kerja Keadilan dan Keterbukaan PNS dalam Membangun Masyarakat Madani dan Demokrasi. Humanus, 10(01), 52-61.

Hamali, S. (2011). Sikap Keagamaan Dan Pola Tingkah Laku Masyarakat Madani. Al-Adyan, 6(2), 77-100.

Hamzah, M. M. (2017). Peran dan Pengaruh Fatwa MUI dalam Arus Transformasi Sosial Budaya di Indonesia. Jurnal Studi Agama, 17(1).

Iswahyudi. (2016). Majelis Ulama Indonesia dan Nalar Fatwa-Fatwa Eksklusif. Jurnal Al-Ahkam, 11(2).

Morris, A. M. (2011). Restorative Justice for Juveniles : Conferending, Mediation and Circles. Hart Publising.

Muhammad Amin, Rod al -Mukhtar 'Ala Dar Al-Mukhtar Juz I, (Beirut: Dar Al-Fikr, 1992), h. 624. (n.d.).

Sajari, D. (2015). Fatwa MUI Tentang Aliran Sesat di Indonesia. Jurnal Miqot, 39(1).

Syafaq. (2014). Kontroversi Seputar Tradisi Keagamaan Popular dalam Masyarakat Islam. ISLAMICA: Jurnal Studi Keislaman, 2(1). 
Yus Afrida

Halaman ini sengaja dikosongkan 